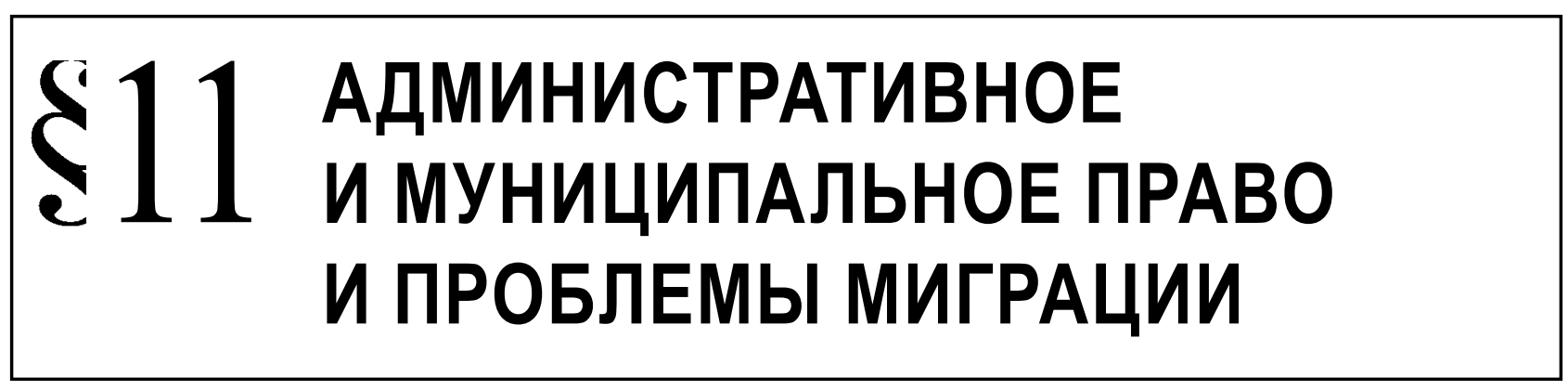

Сизов И.Ю.

\title{
ПРАВОВОЙ ОБЗОР ОТДЕЛЬНЫХ ПРАКТИЧЕСКИХ ПРОБЛЕМ ПОЛУЧЕНИЯ ВИДА НА ЖИТЕЛЬСТВО
}

\begin{abstract}
Аннотация: Данная статья посвящена обзору отдельных практических проблем получения иностранными гражданами вида на жительство. В первую очередь проводится анализ судебного решения, признающего отсутствие в перечне документов, подтверждающих наличие законного источника средств к существованию, справки о наличии вклада в кредитном учреждении не соответствующим законодательству. Исходя из предмет статьи проведен анализ Положения о порядке рассмотрения вопросов гражданства Российской Федераиии, Административного регламента предоставления Федеральной миграционной службой государственной услуги по выдаче иностранным гражданам и лицам без гражданства вида на жительство в Российской Федерачии и других нормативных правовых актов, Методологическую основу статьи составили современные достижения теории познания. В процессе исследования применялись теоретический, общефилософские методы (диалектика, системный метод, анализ, синтез, аналогия, дедукция, наблюдение, моделирование), традиционно правовые методы (формально-логический), а также методы, используемые в конкрет-но-сочиологических исследованиях (статистические, экспертные оченки и др.). В статье отмечается, что административно-правовое регулирование миграции населения является одной из самых актуальных проблем в срере государственного управления. Обусловлено это рядом обстоятельств: демографические проблемы, недостаточная теоретическая проработанность роли и значения миграционных процессов в демографическом развитии Российской Федерации. Эти и другие проблемы провоцируют иелый ряд негативных последствий в сфере обеспечения правопорядка, а также социально-экономического развития страны. Нелегальная миграция с каждым годом все больше и больше заставляет обращать на себя внимание со стороны органов государственной власти.
\end{abstract}

Ключевые слова: вид, жительство, миграчия, контроль, иммиграция, ФМС, виза, выдворение, депортация, иностранец.

$\Pi$ риказом Федеральной миграционной службы от 22 апреля 2013 г. № 215 утвержден Административный регламент предоставления Федеральной миграционной службой государственной услуги по выдаче иностранным гражданам и лицам без гражданства вида на жительство в Российской Федерации (далее - Административный регламент), который устанавливает стандарт и порядок предоставления территориальными органами Федеральной миграционной службы (далее - ФМС России) и их структурными подразделениями государственной услуги по выдаче иностранным гражданам и лицам без гражданства вида на жительство в Российской Федерации (пункт 1).
Пунктом 21.4 Административного регламента предусмотрено, что для получения вида на жительство иностранный гражданин подает в территориальный орган ФМС России документ, подтверждающий наличие законного источника средств к существованию, позволяющего содержать себя в Российской Федерации в пределах прожиточного минимума, или документ, подтверждающий его нетрудоспособность. Такими документами являются: справка о доходах физического лица, справка с места работы, пенсионное удостоверение, подтверждение о получении алиментов, справка о доходах лица, на иждивении которого находится заявитель, патент с документом, подтверждающим уплату налога на доходы физических лиц в виде фиксированного авансового платежа в порядке, 
установленном законодательством Российской Федерации о налогах и сборах, иной документ, подтверждающий получение доходов от не запрещенной законом деятельности или нетрудоспособность.

Возникает вопрос - допустимо ли в качестве документа, подтверждающего наличие законного источника средств к существованию, иностранному гражданину представлять справку о наличии вклада в кредитном учреждении. Верховный Суд России признал данный пункт не соответствующим законодательству, поскольку после перечисления документов, подтверждающих наличие у иностранного гражданина законного источника средств к существованию, позволяющего содержать себя в Российской Федерации в пределах прожиточного минимума (справка о доходах физического лица, справка с места работы, пенсионное удостоверение, подтверждение о получении алиментов, справка о доходах лица, на иждивении которого находится заявитель, патент с документом, подтверждающим уплату налога на доходы физических лиц в виде фиксированного авансового платежа в порядке, установленном законодательством Российской Федерации о налогах и сборах), пункт 21.4 Административного регламента содержит указание на иной документ, подтверждающий получение доходов от не запрещенной законом деятельности. Между тем к документам, подтверждающим получение доходов от не запрещенной законом деятельности, справка о наличии вклада в кредитном учреждении не относится ${ }^{1}$.

Однако данное решение суда, по нашему мнению, не вполне соответствует смыслу и логике законодательства. Правовое положение иностранных граждан в Российской Федерации определяется Федеральным законом от 25.07.2002 № 115-Ф3 «0 правовом положении иностранных граждан в Российской Федерации», который также регулирует отношения между иностранными гражданами, с одной стороны, и органами государственной власти, органами местного самоуправления, должностными лицами указанных органов, с другой стороны, возникающие в связи с пребыванием (проживанием) иностранных граждан в Российской Федерации и осуществлением ими на территории Российской Федерации трудовой, предпринимательской и иной деятельности.

Согласно подпункту 8 пункта 1 статьи 9 Федерального закона вид на жительство иностранному гражданину не выдается, а ранее выданный вид на жительство аннулируется в случае, если данный 1 Решение Верховного Суда РФ от 08.07.2014 № АКПИ14-
642 // Документ опубликован не был. иностранный гражданин не может представить доказательств возможности содержать себя и членов своей семьи в Российской Федерации в пределах прожиточного минимума, не прибегая к помощи государства, за исключением случая, если иностранный гражданин признан нетрудоспособным.

В соответствии с пунктом 5 статьи 8 Федерального закона порядок выдачи или продления срока действия вида на жительство, форма заявления о выдаче или продлении срока действия вида на жительство, а также порядок подачи заявлений в форме электронных документов с использованием информационнотелекоммуникационных сетей общего пользования, в том числе сети Интернет, включая единый портал государственных и муниципальных услуг, утверждается федеральным органом исполнительной власти в сфере миграции. Перечень документов, представляемых одновременно с заявлением о выдаче или продлении срока действия вида на жительство, в том числе представляемых в форме электронного документа, утверждается федеральным органом исполнительной власти в сфере миграции.

Из приведенных норм следует, что выдача иностранному гражданину вида на жительство зависит от представления им доказательств возможности содержать себя и членов своей семьи в Российской Федерации в пределах прожиточного минимума, не прибегая к помощи государства. При этом, наделяя федеральный орган исполнительной власти в сфере миграции полномочием на утверждение перечня документов, представляемых одновременно с заявлением о выдаче вида на жительства, законодатель не установил, что возможность иностранного гражданина содержать себя и членов его семьи в Российской Федерации в пределах прожиточного минимума должна быть подтверждена лишь определенными доказательствами, к которым справка о наличии вклада в кредитном учреждении с указанием номера счета не относится.

Таким образом, по смыслу Федерального закона, указанная справка, подтверждающая наличие достаточной суммы денежных средств, имеющихся на вкладе в кредитном учреждении, может быть представлена в качестве доказательства в подтверждение наличия у иностранного гражданина законного источника средств к существованию, позволяющего содержать себя и членов своей семьи в Российской Федерации в пределах прожиточного минимума².

\footnotetext{
2 См.: Куракин А.В. Иностранные граждане и лица без гражданства как субъекты административного права России // Государство и право. - 2001. - № 6. - С. 16.
} 
Данный вывод согласуется и с содержанием пункта 10 Положения о порядке рассмотрения вопросов гражданства Российской Федерации, утвержденного Указом Президента Российской Федерации от 14 ноября 2002 г. № 1325, в котором справка о наличии вклада в кредитном учреждении с указанием номера счета названа в числе документов, подтверждающих наличие у иностранного гражданина законного источника средств к существованию.

В качестве дополнительного аргумента можно привести и то, что перечень документов, подтверждающих получение иностранным гражданином доходов от не запрещенной законом деятельности, установленный пунктом 21.4 Административного регламента, не является исчерпывающим. Более того, исходя из абзаца четвертого пункта 10 Положения о порядке рассмотрения вопросов гражданства Российской Федерации, утвержденного Указом Президента Российской Федерации от 14 ноября 2002 г. № 1325, справка о наличии вклада в кредитном учреждении с указанием номера счета относится к документам, подтверждающим наличие законного источника средств к существованию. Таким образом, вывод о том, что рассматриваемое положение противоречит законодательству представляется преждевременным.

\section{Библиография:}

1. Куракин А.В. Иностранные граждане и лица без гражданства как субъекты административного права России // Государство и право. - 2001. - № 6.

2. Куракин А.В. Контроль органов внутренних дел за соблюдением правил пребывания в Российской Федерации иностранных граждан и лиц без гражданства. - М., 2002.

3. Облезова (Харитонова) А.О. Новое в миграционном законодательстве: введение ответственности за непринятие приглашающей стороной мер по обеспечению приглашенного иностранного гражданина // Миграционное право. - 2013. - № 1 .

4. Вострокнутова О.Ю. К вопросу о совершенствовании административно-правового регулирования миграционной политики Российской Федерации. // Полицейская деятельность. - 2011. - 1. - С. 38 - 41.

5. Сизов И.Ю. Проблемы информационного обеспечения деятельности органов внутренних дел при противодействии миграционной преступности // Полицейская деятельность. - 2012. - 1. - С. 26 - 30.

6. Сизов И.Ю. Административно-правовой механизм миграционного учета // Административное и муниципальное право. - 2012. - 5. - С. 58 - 63.

7. Сизов И.Ю. Административно-правовое регулирование вынужденной миграции // Административное и муниципальное право. - 2012. - 3. - С. 5 - 9.

8. Куракин А.В. Правовое регулирование банковской деятельности в Российской Федерации (административноправовой аспект) // NB: Административное право и практика администрирования. - 2013. - 11. - С. 69 - 100. DOI: 10.7256/2306-9945.2013.11.10603. URL: http://www.e-notabene.ru/al/article_10603.html

9. Купреев С.С., Рябчиков Ю.И. Институт административной высылки иностранцев по законодательству Российской Федерации // Полицейская деятельность. - 2012. - 4. - С. 17 - 26.

\section{References (transliterated):}

1. Kurakin A.V. Inostrannye grazhdane i litsa bez grazhdanstva kak sub"ekty administrativnogo prava Rossii // Gosudarstvo i pravo. - 2001. - № 6 .

2. Kurakin A.V. Kontrol' organov vnutrennikh del za soblyudeniem pravil prebyvaniya v Rossiiskoi Federatsii inostrannykh grazhdan i lits bez grazhdanstva. - M., 2002.

3. Oblezova (Kharitonova) A.O. Novoe v migratsionnom zakonodatel'stve: vvedenie otvetstvennosti za neprinyatie priglashayushchei storonoi mer po obespecheniyu priglashennogo inostrannogo grazhdanina // Migratsionnoe pravo. - 2013. - № 1.

4. Vostroknutova O.Yu. K voprosu o sovershenstvovanii administrativno-pravovogo regulirovaniya migratsionnoi politiki Rossiiskoi Federatsii. // Politseiskaya deyatel'nost'. - 2011. - 1. - C. 38 - 41.

5. Sizov I.Yu. Problemy informatsionnogo obespecheniya deyatel'nosti organov vnutrennikh del pri protivodeistvii migratsionnoi prestupnosti // Politseiskaya deyatel'nost'. - 2012. - 1. - C. 26 - 30.

6. Sizov I.Yu. Administrativno-pravovoi mekhanizm migratsionnogo ucheta // Administrativnoe i munitsipal'noe pravo. 2012. - 5. - C. 58 - 63.

7. Sizov I.Yu. Administrativno-pravovoe regulirovanie vynuzhdennoi migratsii // Administrativnoe i munitsipal'noe pravo. - 2012. - 3. - C. 5 - 9.

8. Kurakin A.V. Pravovoe regulirovanie bankovskoi deyatel'nosti v Rossiiskoi Federatsii (administrativno-pravovoi aspekt) // NB: Administrativnoe pravo i praktika administrirovaniya. - 2013. - 11. - C. 69 - 100. DOI: 10.7256/23069945.2013.11.10603. URL: http://www.e-notabene.ru/al/article_10603.html

9. Kupreev S.S., Ryabchikov Yu.I. Institut administrativnoi vysylki inostrantsev po zakonodatel'stvu Rossiiskoi Federatsii // Politseiskaya deyatel'nost'. - 2012. - 4. - C. 17 - 26. 